\title{
BMJ Substandard and falsified medicines Open in the UK: a retrospective review of drug alerts (2001-2011)
}

\author{
Tariq Almuzaini, Helen Sammons, Imti Choonara
}

To cite: Almuzaini T, Sammons H, Choonara I. Substandard and falsified medicines in the UK: a retrospective review of drug alerts (2001-2011). BMJ Open 2013;3:e002924. doi:10.1136/bmjopen-2013002924

- Prepublication history and additional material for this paper are available online. To view these files please visit the journal online (http://dx.doi.org/10.1136/ bmjopen-2013-002924).

Received 27 March 2013 Revised 17 May 2013 Accepted 16 June 2013

Academic Division of Child Health, University of Nottingham, Derbyshire Children's Hospital, Derby, UK

Correspondence to Tariq Almuzaini; mzxta@ exmail.nottingham.ac.uk

\section{ABSTRACT}

Objective: To determine the extent of substandard and falsified medicines in the UK.

Design: A retrospective review of drug alerts and company-led recalls.

Setting: The Medicines and Healthcare Products Regulatory Agency (MHRA) website search for drug alerts issued between 2001 and 2011.

Eligibility criteria: Drug alerts related to quality defect in medicinal products.

Main outcome measure: Relevant data about defective medicines reported in drug alerts and company-led recalls, including description of the defect, type of formulation, year of the alert and category of the alert.

Results: There were 280 substandard medicines of which 222 were recalled. The two most frequent problems were contamination (74 incidents) and issues related to packaging (98 incidents). Formulations for parenteral administration (117 incidents) were the formulation most frequently affected. There were 11 falsified medicines, as defined by the MHRA, reported over the 11-year period. The number of defective medicines reported by the MHRA increased 10-fold from 5 in 2001 to 50 in 2011.

Conclusions: Substandard medicines are a significant problem in the UK. It is uncertain whether the increasing number of reports relates to improved detection or an increase in the number of substandard medicines.

\section{INTRODUCTION}

Falsified and substandard medicines are a significant problem throughout the world. ${ }^{1-4}$ Most of the evidence for this has been reported from Africa and Asia in low and lower middle income countries. ${ }^{1-3}$ Little evidence, however, is available for European and Northern American countries, as no individual studies about the problem have been published in high-income countries. According to European commission data, the incidence of this problem in the European supply chain is growing by $10-20 \%$ annually. ${ }^{5} 6$

\section{ARTICLE SUMMARY}

Article focus

- To describe the pattern of drug alerts issued by the Medicines and Healthcare Products Regulatory Agency (MHRA) in the UK from 2001 to 2011.

- To determine the extent of substandard and falsified medicines in the UK.

\section{Key messages}

- Substandard medicines are a significant problem in the UK, with a 10-fold increase in the incidents reported over the last 10 years.

- Formulations for parenteral administration were most likely to be substandard.

- Education of healthcare professionals in the initial assessment of quality of medicines, especially parenteral formulation, is needed.

Strengths and limitations of this study

- This is the first review to assess the problem of substandard and falsified medicines in a highincome country.

- Quantification of all drug alerts issued by the MHRA over an 11-year period.

- Clinical significance of the problem is unknown due to the lack of available data from the MHRA or the manufacturers on the adverse events related to defective medicines.

- We were not able to determine the reason(s) for the rise of drug alerts, owing to the limited data available.

In the UK, the Medicines and Healthcare products Regulatory Agency (MHRA) has the responsibility of safeguarding the public from the risk of these drugs. The MHRA's Defective Medicines Report Centre (DMRC) is the department responsible for receiving and assessing reports about suspected defective drugs. Drug alerts are issued by the DMRC to the manufacturer, wholesalers and healthcare providers, in cases where a defective medicine is shown to compromise patients' safety. ${ }^{7}$

The aims of this study were to describe the number of drug alerts issued by the MHRA 
and to determine the extent of substandard and falsified medicines in the UK.

\section{METHODS}

The DMRC defines a defective drug as a "drug which proves to be harmful under normal conditions of use, lacking in therapeutic efficacy and/or the qualitative and quantitative composition of a drug is not as declared. A drug can also be defective if the controls on a drug and/or on the ingredients and the controls at an intermediate stage of the manufacturing process have not been carried out or if some other requirement or obligation relating to the grant of the manufacturing authorisation has not been fulfilled."

There is currently no agreed international definition of a falsified medical product. The 2011 WHO definition of substandard/spurious/falsely labelled/falsified/ counterfeit medical products does not differentiate between different types of compromised medicines that need distinct regulatory actions. ${ }^{9}$ Attaran $e t ~ a l^{4}$ have proposed a clearer definition, differentiating between falsified and substandard medicines in relation to if a medicine is a public health crime, and therefore an intentional wrong doing, or if there has been a regulatory failure and no intentional wrong has taken place. No specific definition exists within English law and the MHRA adopts the definition contained within the European Falsified Medicines Directive. They look for clear evidence that there was an intention to deceive a consumer, patient, healthcare professional and/or operator within the supply chain, into believing that the medical product being manufactured offered or supplied was the genuine article when in fact it was not. ${ }^{10}$ In this paper, we define medicines that failed to pass the quality measurements and standards set for them as substandard medicines. On the contrary, falsified medicines are those which do not meet the quality specifications of regulatory authority with deliberate intent.

A search for drug alerts related to defective medicinal products was carried out. This was performed through the official MHRA website using the section allocated for drug alerts. The first drug alert reported on the MHRA website was in the year 2001; thus, all drug alerts issued between 2001 and 2011 were included. Manufacturers can also voluntarily recall their defective products without the need for a drug alert to be issued by the MHRA in cases where defective medicines have left manufacturing sites but have had limited distribution in the supply chain. The MHRA started posting these recalls under its company-led recall section in 2011; hence, all these recalls were included. The resulting alerts and recalls were compiled and exclusion criteria included the following: drug alert replaced by another updated one, drug alert duplication, alert about clarification of medicine information, medical device alert and alert about medicines lacking efficacy or having significant toxicity.
The following data were extracted from these alerts: name, strength and dosage form; year of the alert; number of affected batches; nature of the defect; class of drug alert and action to be taken about defective medicine. Substandard medicines were then subdivided according to the type of the defect into the following:

- Contamination: Defect related to microbial contaminations and issues related to sterility as well as chemical and particulate (ie, impurities) contamination.

- Minor packaging defect: Defects that occur in relation to the printing of packaging materials, for instance, printed box errors that involve a missing or incorrect expiry date or batch number of a medicine. This also includes any errors in the patients' information leaflets or summary of product characteristic.

- Major packaging defects: A defect that involves packing a medicine in a wrong box or carton or printing errors that involve missing or incorrect name or strength of a medicine.

- Delivery: A technical or physical defect such as broken capsules or leaking containers.

- Stability failure. Defect results from the failure of the medicine to remain within the established standards throughout the expiration period, for example, low assay of the active ingredient prior to a product expiry.

- Potency: Failure of the medicine to evoke the desired effect within the stated strength.

- Defect in active ingredient: Defect results from the active ingredient being inadequate or excessive in the formulation.

- Other defects: Other deviations concerning noncompliance with good manufacturing practice at manufacturing site.

The total number of alerts was obtained and each individual medicine reported in these alerts was then extracted. Defective medicines were then classified according to the WHO Anatomical Therapeutic Chemical Classification System. This system uses five levels to classify medicines and the first two levels were used in this section. The first level classifies medicine according to the system or organ on which the medicine acts; whereas, the second level classifies medicine according to its main therapeutic group. ${ }^{11}$

Company-led recalls are initiated by manufacturers after consultation with the MHRA, without giving the recall any degree of urgency. Drug alerts, by contrast, are issued by the MHRA and have four possible classifications based on the level of the risk. ${ }^{8}$ These classes are as follows:

- Class 1 drug alert: The defect in a medicine is lifethreatening and poses a serious risk to patient health.

- Class 2 drug alert: The defect in a medicine is not lifethreatening but can still be harmful to patients.

- Class 3 drug alert: The defect in a medicine is unlikely to be hazardous to patients, but an alert is issued, due to problems related to non-compliance with good manufacturing practices or marketing authorisations. 
- Class 4 drug alert: The least critical alert; advises "caution in use".

Classes 1, 2 and 3 drug alerts require recalls of affected batches, whereas class 4 alerts do not require recalls but require caution in dealing with defective medicines. $^{8}$

Three types of compromised medicine can be recognised in the alerts; namely: falsified, substandard and medicines withdrawn because of safety or toxicity concerns. The decision of which medicines were falsified was made from the MHRA classification. ${ }^{12}$ Only medicines where it was made clear in the recall that the batch was regarded by the MHRA as counterfeit/falsified were given this label. No data were available to the authors to further analyse if the error was intentional or non-intentional. All alerts that were not included in the MHRAs' specific falsified medical products list were therefore classified as substandard medicines.

\section{RESULTS}

\section{Incident trends}

There were a total of 244 drug alerts issued by the MHRA. After applying the aforementioned exclusion criteria, 30 were excluded. In turn, 214 were deemed suitable for inclusion (figure 1). Analysis showed that these alerts reported 269 medicines, each of which represented an individual incident. The majority of these alerts were issued for individual medicines. However, some were issued for up to 14 medicines.

Since MHRA started reporting drug alerts online in 2001, there has been a gradual increase in the rate of drug alerts related to defective medicinal products. The number of drug alerts increased from 5 in 2001 to 31 in 2011. The number of defective medicines reported by these alerts was five in 2001. This figure increased 10 -fold by 2011, to a total of 50 (figure 2).

\section{Defective medicines recalled by the MHRA under classes 1-4 drug alerts}

Seventeen medicines were recalled under class 1 drug alerts. The highest number of alerts was issued for contamination reasons. The most frequent formulations reported were formulations for parenteral administration, which accounted for seven cases. The median time, when stated, taken by the MHRA to identify these medicines as defective, from medicines being available on the market, to issuing alerts was 64 days (range 13-242 days). The length of this time period is critical, as the chance of adverse events increases as the time of exposure increases. Details of these alerts are shown in table 1.

Under class 2 alert, 161 medicines were recalled. The main issues were related to contamination and minor packaging defects. There were also 87 medicines recalled under class 3 or 4 alerts (see online supplementary table $\mathrm{S} 1$ ).
Defective medicines recalled by manufacturers (company-led recalls)

It was observed that 19 company-led recalls were issued by the manufacturers in 2011. One recall was excluded after applying the exclusion criteria. Thus, 18 company-led recalls were included and these were issued for a total of 22 defective medicines (figure 1).

\section{Defective medicines, classified by type of defect}

The incidents of defective medicines reported by the MHRA (269) were compiled with those reported by the manufacturers (22), which resulted in 291 incidents to be considered for further analysis.

\section{Substandard medicines}

Defects in substandard medicines accounted for the bulk of these incidents. Two hundred and eighty medicines $(96 \%)$ were reported to be substandard (figure 1). A total of 222 medicines were recalled. The two most frequent problems, with the substandard medicines, were packaging and contamination (table 2). Contamination was a significant issue with parenteral formulations where there were a total of 60 incidents (see online supplementary table S2). Formulations for parenteral administration were most frequently affected by quality issues, with a total of 117 incidents (42\%). Formulations for intravenous administration accounted for the majority of the cases (89 incidents). Other formulations affected were subcutaneous (15 incidents) and intramuscular formulations (12 incidents).

Packaging defects were the other most frequent problem. In many cases these involved significant clinical issues such as incorrect name, strength or active ingredient of a medicine on the packaging or errors in the product information leaflet in relation to administration or toxicity. The number of defective medicines was highest among drugs that act on the nervous system (45/ 280), cardiovascular system (41) and infections (35). When these medicines were classified by therapeutic class, those most frequently reported defective were antihypertensives $(27 / 280)$, antineoplastic agents $(21 / 280)$ and antibacterials (19/280). Details are given in online supplementary table S3.

The UK Health and Social Care Information Centre published a list of the 20 drugs that contained the greatest number of items dispensed in 2011 by volume. ${ }^{13}$ Ten of these 20 medicines were associated with a total of 22 incidents of substandard medicines.

The study identified 89 manufacturers, holding the marketing authorisation for 280 medicines which were recalled by the MHRA. Manufacturers who held the marketing authorisation of five or more recalled medicines are listed in online supplementary table S4. Fifteen manufacturers fit this criterion. Together, they hold the authorisation for 163 medicines, accounting for $58 \%$ of all recalled medicines. The majority of these manufacturers have manufacturing facilities in the UK, four having headquarters in the UK (Glaxosmithkline, 


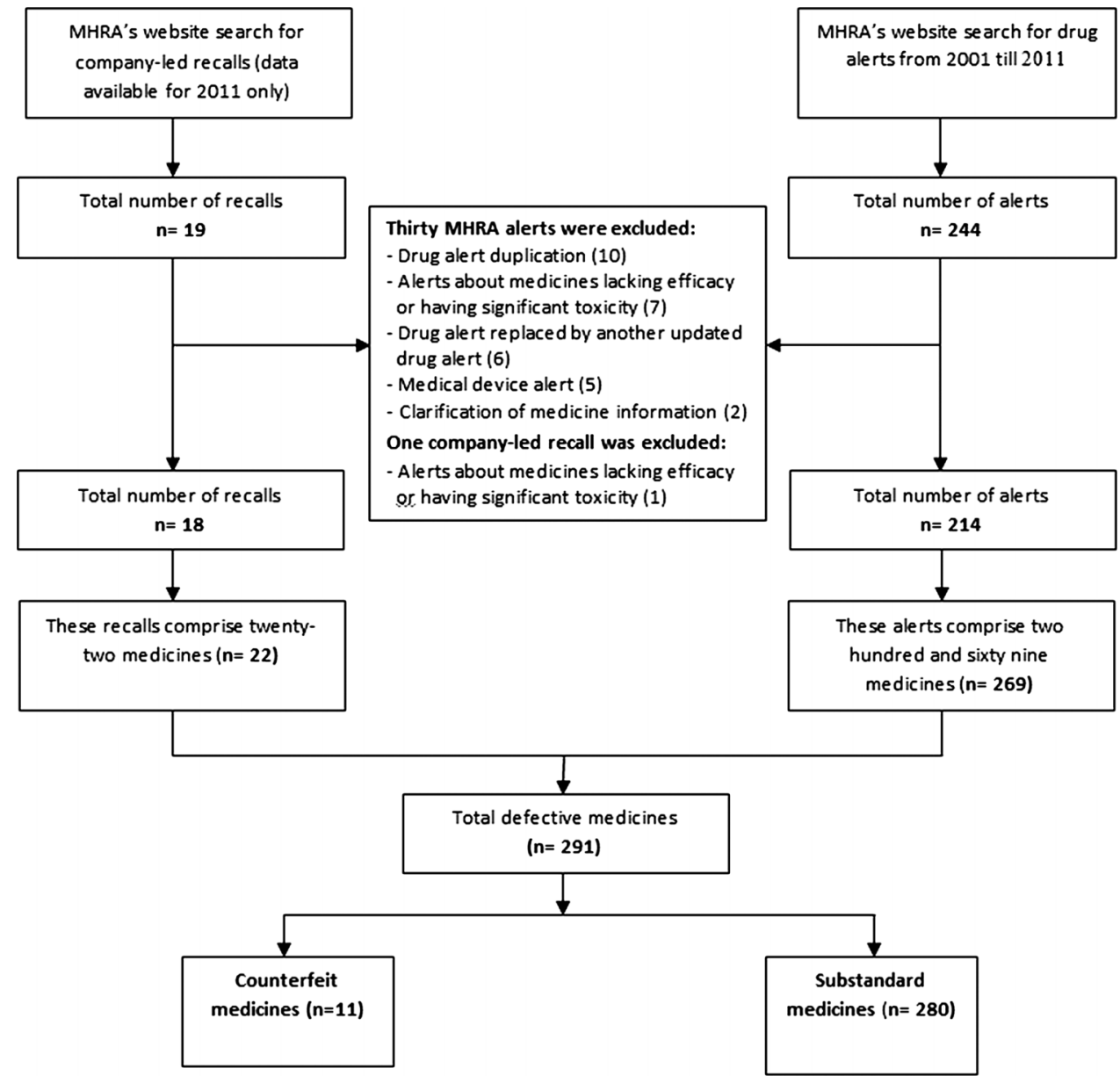

Figure 1 Flow diagram of search and resulting alerts and recalls.

AstraZeneca, Martindale Pharmaceuticals and Karib Kemi Pharm). The online supplementary table S4 also describes individual manufacturing defects for all listed manufacturers.

\section{Falsified medicines}

Since 2004, 11 incidents of falsified drugs have been reported by the MHRA that breached the UK supply chain (table 3). The last of these was reported in 2009.
In 2007 alone, the MHRA stated in its falsified medical products strategy (2012-2015) that more than two million doses of falsified medicines entered the supply chain. ${ }^{10} \mathrm{~A}$ total of 700000 doses were recalled from pharmacies or patients. ${ }^{10}$ In these alerts, information regarding the actual problems with the falsified medicines is given for only 2 of the 11 incidents reported. In its recent strategy on falsified medicines, the MHRA stated that the previous falsified medicines seized had
Figure 2 Number of drug alerts and defective medicines reported in the Medicines and Healthcare Products Regulatory Agency alerts from 2001 to 2011.

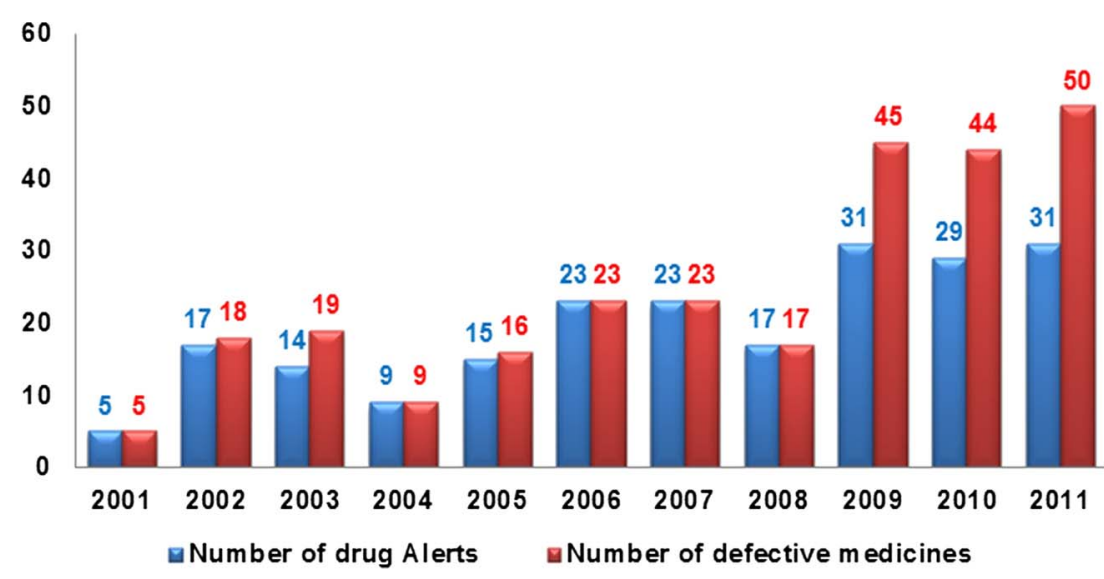




\begin{tabular}{|c|c|c|c|c|}
\hline Type of defect & Medications & Formulation & Defect description & $\begin{array}{l}\text { Time taken for the MHRA to issue drug } \\
\text { alerts from the first distribution of } \\
\text { defective batches (days) }\end{array}$ \\
\hline \multicolumn{5}{|l|}{ Substandard medicines } \\
\hline \multirow[t]{6}{*}{ Contamination } & Zinc oxide BP $15 \%$ w/w & $\begin{array}{l}\text { Local } \\
\text { preparation }\end{array}$ & Lack of sterility assurance & 19 \\
\hline & Etoposide 20 mg/mL & Injection & Lack of sterility assurance & Not stated \\
\hline & Paclitaxel $6 \mathrm{mg} / \mathrm{mL}$ & Injection & Lack of sterility assurance & Not stated \\
\hline & Tetrofosmin $230 \mu \mathrm{g}$ & Injection & $\begin{array}{l}\text { Gas filters used in the aseptic manufacturing } \\
\text { process were not sterile }\end{array}$ & 33 \\
\hline & Rabies vaccine & Injection & $\begin{array}{l}\text { low level of contamination with live attenuated } \\
\text { rabies virus }\end{array}$ & 64 \\
\hline & Nelfinavir mesilate & $\begin{array}{l}\text { All } \\
\text { presentations }\end{array}$ & $\begin{array}{l}\text { Contaminated originator and parallel distributed } \\
\text { product }\end{array}$ & Not stated \\
\hline \multirow[t]{3}{*}{ Major packaging defects } & Ibuprofen & Tablets & $\begin{array}{l}\text { The product contained rogue quetiapine } \mathrm{XL} \\
50 \mathrm{mg} \text { tablets and gabapentin } 100 \mathrm{mg} \text { capsules }\end{array}$ & 117 \\
\hline & $\begin{array}{l}\text { Ephedrine hydrochloride } \\
3 \mathrm{mg} / \mathrm{mL}\end{array}$ & Injection & $\begin{array}{l}\text { Ephedrine hydrochloride syringe in a plastic box } \\
\text { erroneously identified as atropine sulfate } \\
\text { injection }\end{array}$ & 44 \\
\hline & $\begin{array}{l}\text { Bendroflumethiazide } \\
2.5 \mathrm{mg}\end{array}$ & Tablets & This batch contains warfarin $3 \mathrm{mg}$ tablets & 210 \\
\hline \multirow[t]{4}{*}{ Delivery issues } & Temozolomide* & Capsules & Reports of broken capsules and leakage & 38 \\
\hline & Temozolomide* & Capsules & Reports of broken capsules and leakage & 91 \\
\hline & Fentanyl $(40 \mu \mathrm{g} / \mathrm{dose})$ & $\begin{array}{l}\text { Transdermal } \\
\text { system }\end{array}$ & $\begin{array}{l}\text { One batch of the transdermal system have been } \\
\text { found to self-activate which has the potential to } \\
\text { cause overdose }\end{array}$ & Not stated \\
\hline & Salbutamol $100 \mu \mathrm{g}$ & Inhaler & $\begin{array}{l}\text { Fault with the valve which may lead to higher } \\
\text { doses }\end{array}$ & 120 \\
\hline Potency issues & $\begin{array}{l}\text { Fentanyl compressed } \\
\text { lozenge }\end{array}$ & $\begin{array}{l}\text { Compressed } \\
\text { lozenge }\end{array}$ & $\begin{array}{l}\text { The potency of the product is out of } \\
\text { specification }\end{array}$ & 242 \\
\hline \multirow[t]{2}{*}{$\begin{array}{l}\text { Issues relating to active } \\
\text { pharmaceutical ingredient }\end{array}$} & $\begin{array}{l}\text { Oxybutynin hydrochloride } \\
5 \mathrm{mg}\end{array}$ & Tablets & Excessive amount of active ingredient & 56 \\
\hline & $\begin{array}{l}\text { Enoxaparin sodium } 20 \\
\text { and } 40 \mathrm{mg}\end{array}$ & Injection & Excessive amount of active ingredient & 207 \\
\hline Other issues & $\begin{array}{l}\text { Protamine sulfate } 10 \mathrm{mg} / \\
\mathrm{mL}\end{array}$ & Injection & $\begin{array}{l}\text { Failure of the finished product to meet normal } \\
\text { assay criteria }\end{array}$ & 13 \\
\hline
\end{tabular}


Table 2 Substandard medicines

\begin{tabular}{|c|c|c|c|c|}
\hline Defect type & $\begin{array}{l}\text { Number of } \\
\text { medicines }\end{array}$ & $\begin{array}{l}\text { Per } \\
\text { cent }\end{array}$ & Defect details & $\begin{array}{l}\text { Number of } \\
\text { medicines }\end{array}$ \\
\hline \multirow[t]{3}{*}{ Contamination } & 74 & 27 & Impurities & 44 \\
\hline & & & Lack of sterility assurance & 18 \\
\hline & & & Microbial contamination & 12 \\
\hline \multirow[t]{4}{*}{$\begin{array}{l}\text { Minor packaging } \\
\text { defects }\end{array}$} & 70 & 25 & $\begin{array}{l}\text { Failure to update PIL with administration or safety } \\
\text { warning }\end{array}$ & 40 \\
\hline & & & $\begin{array}{l}\text { Incorrect information/description of the dosage form, } \\
\text { strength or dose of a medicine }\end{array}$ & 12 \\
\hline & & & Missing or packing PIL with the wrong carton & 6 \\
\hline & & & Others & 12 \\
\hline \multirow[t]{3}{*}{ Delivery defects } & 33 & 12 & Fault with a device & 19 \\
\hline & & & Leakage or loose seal & 9 \\
\hline & & & Others & 5 \\
\hline \multirow[t]{2}{*}{$\begin{array}{l}\text { Major packaging } \\
\text { defects }\end{array}$} & 28 & 10 & $\begin{array}{l}\text { Missing or incorrect name ,strength, or active } \\
\text { ingredient of a medicine on carton or box }\end{array}$ & 22 \\
\hline & & & Packing a medicine in the wrong carton & 6 \\
\hline \multirow[t]{2}{*}{ Stability defects } & 23 & 8 & Unspecified stability failure & 15 \\
\hline & & & $\begin{array}{l}\text { Stability failure of the active ingredient or dissolution } \\
\text { failure prior to expiry }\end{array}$ & 8 \\
\hline \multirow[t]{2}{*}{$\begin{array}{l}\text { Defects in active } \\
\text { ingredient }\end{array}$} & 8 & 3 & $\begin{array}{l}\text { Active ingredient is out of specification (either more or } \\
\text { less) }\end{array}$ & 6 \\
\hline & & & $\begin{array}{l}\text { Non-homogeneity of the active ingredient in the } \\
\text { formulation }\end{array}$ & 2 \\
\hline Potency & 7 & 2 & $\begin{array}{l}\text { Subpotent medicine (underlying causes of subpotency } \\
\text { were not stated) }\end{array}$ & 7 \\
\hline \multirow[t]{2}{*}{ Other defects } & 37 & 13 & $\begin{array}{l}\text { GMP deficiencies at manufacturing site or improper } \\
\text { storage of medicines during shipment }\end{array}$ & 23 \\
\hline & & & Others & 14 \\
\hline Total & 280 & 100 & & 280 \\
\hline
\end{tabular}

one or more quality defect issues concerning active ingredients, disintegration, dissolution or presence of unknown impurities. ${ }^{10}$

\section{DISCUSSION}

This review has shown that the problem of defective medicines reported in the UK has increased 10-fold over the 11 years studied. It is likely that the incidence of defective medicines has actually increased in the UK, but there is insufficient data to prove this. The most frequent formulations reported to be defective were the formulations for parenteral administration, which accounted for $42 \%$ of cases. Substandard medicines represented the bulk of defective medicine incidents, accounting for over $95 \%$ of the cases. Contamination issues were the most frequently reported clinically relevant problems reported; $80 \%$ of these contaminated formulations were formulations for parenteral administration. There is a greater likelihood of harm to the patient in association with contaminated parenteral formulations as highlighted by the recent outbreak of fungal sepsis in the USA. ${ }^{14}$ However, these adverse health consequences have not been documented by the MHRA or the manufacturers.

\section{Substandard medicines}

It is not clear whether the increase in the trend of substandard medicines incidents resulted from new legislation or strategies by the MHRA, that have made it easier to detect and report these drugs, or whether the rate of manufacture of substandard medicines in the UK is increasing. The overall performance of the MHRA has improved since it was officially launched in $2003 .{ }^{15} 16$ The introduction and development of the MHRA's website since $2003 / 2004$, as well as the addition of an integrated site for medicines and medical devices, opened important communication channels with healthcare providers and stakeholders. ${ }^{15}$ The MHRA has introduced guidelines to healthcare professionals outlining procedures for reporting medicines suspected to be defective. ${ }^{8}$ These guidelines outline the role that healthcare professionals play in the initial assessment of suspected defected medicines. They also illustrate subsequent investigations that can be carried out by the DMRC before it issues a drug alert. The ease of access to these guidelines through the MHRA's website may increase healthcare providers' awareness about how to deal with these drugs. It is now possible to report these drugs online or over the phone if the healthcare professional thinks that the defect in a drug may represent a serious risk to public health. 
Table 3 Drug alerts relating to falsified medicines

\begin{tabular}{|c|c|c|c|c|c|c|}
\hline Number & Medicines & Year & Formulation & Recall level & $\begin{array}{l}\text { Stated problem/defect } \\
\text { description }\end{array}$ & $\begin{array}{l}\text { Class of } \\
\text { drug alert } \\
(1-4)\end{array}$ \\
\hline 1 & $\begin{array}{l}\text { Salmeterol } 25 \mu \mathrm{g} / \text { fluticasone } \\
\text { propionate } 250 \mu \mathrm{g} \text { (seretide } \\
250 \text { ) }\end{array}$ & 2009 & Evohaler & $\begin{array}{l}\text { Pharmacy and } \\
\text { wholesaler }\end{array}$ & A reduced patient dose & 2 \\
\hline 2 & $\begin{array}{l}\text { Sensodyne original and } \\
\text { sensodyne mint in } 50 \mathrm{~mL} \\
\text { tubes }\end{array}$ & 2007 & Toothpaste & Caution & $\begin{array}{l}\text { Counterfeit toothpaste } \\
\text { contains diethylene glycol } \\
\text { (nephrotoxic and neurotoxic } \\
\text { poison) }\end{array}$ & 4 \\
\hline 3 & Clopidogrel 75 mg (Plavix)* & 2007 & Tablets & Pharmacy | & & 1 \\
\hline 4 & $\begin{array}{l}\text { Bicalutamide } 50 \mathrm{mg} \\
\text { (Casodex) }\end{array}$ & 2007 & Tablets & Patient & & 1 \\
\hline 5 & Clopidogrel 75 mg (Plavix)* & 2007 & Tablets & Pharmacy & & 1 \\
\hline 6 & Olanzapine 10 mg (Zyprexa) & 2007 & Tablets & Patient & Not likely to pose an & 1 \\
\hline 7 & Atorvastatin $20 \mathrm{mg}$ (Lipitor) $^{\star}$ & 2006 & Tablets & Pharmacy & immediate risk to patients. & 2 \\
\hline 8 & Atorvastatin $20 \mathrm{mg}$ (Lipitor) ${ }^{*}$ & 2006 & Tablets & Pharmacy & (parallel imported product) & 2 \\
\hline 9 & Atorvastatin 20 mg (Lipitor) & 2005 & Tablets & Pharmacy & & 2 \\
\hline 10 & $\begin{array}{l}\text { Sibutramine } 15 \mathrm{mg} \\
\text { (Reductil) }\end{array}$ & 2004 & Capsules & Patient & & 2 \\
\hline 11 & Tadalafil 20 mg (Cialis) & 2004 & Tablets & Patient & & 2 \\
\hline
\end{tabular}

These developments may facilitate the reporting of defective drugs by healthcare providers or by manufacturers. In 2003/2004, the DMRG received 298 reports about defective medicines. ${ }^{15}$ The number of these reports has increased, totalling 830 in 2010/2011. ${ }^{16}$ However, the level of awareness of healthcare professionals about these drugs and how to report them has not been tested. For this reason, the possibility cannot be excluded that the real incidence as well as the rate of manufacturing of poor-quality medicines are increasing.

It was of concern that parenteral formulations for intravenous injection or infusion where the formulation most likely to be substandard. The risk of drug toxicity is far greater with drugs given intravenously than those given orally. The toxicity associated with substandard medicines worldwide is unknown. ${ }^{17}$ Healthcare professionals should therefore be aware of the expected risk. Healthcare providers should be educated in the initial assessment of medicines, especially parenteral formulations, for any sign of impurity, particulate contamination or improper sealing. If anything appears suspicious, the healthcare providers should know how to report this defect immediately to the DMRC before any further harm can occur.

\section{Falsified medicines}

The majority of falsified medicine incidents were reported by the MHRA in the period between 2004 and 2007. Information regarding the actual quality-defect type beyond authenticity has been stated for only two cases. Information on the other nine cases has been requested from the MHRA but has not been provided. Five incidents of falsified drugs were reported in 2007 alone. This led the MHRA to introduce its first anticounterfeiting strategy in $2007 .^{18}$ The strategy outlined a 3-year plan to combat falsified medicines through a visionary programme of communication, collaboration and regulation. Since then, the MHRA has reported only one incident in 2009. This may be attributed to the effectiveness of this strategy in reducing the availability of these drugs in the UK supply chains.

The UK has a stringent regulatory oversight of the supply chain, which is represented by the few cases of falsified medicines reported over an 11-year period. Falsified medicines are frequently manufactured abroad and imported to the UK. ${ }^{10}$ The criminal may choose the internet for distribution (given that it is less regulated). Thus, the problem of drug counterfeiting is exacerbated by unregulated online pharmacies. Patients may use the internet because of the following: the anonymity of the internet, offering cheaper medications and receiving prescription-only drugs without prescription. ${ }^{19}$ Falsified drugs do not comply with prerequisite quality and safety standards and therefore are hazardous to patients' health, being at best clinically ineffective and at worst can cause death. The public needs to be made aware of this risk. Adverse events of these drugs have been reported in different countries, ${ }^{2021}$ including the UK. ${ }^{22}$

Falsified medicines are criminal problem according to the law enforcement agencies and a menace to public health. Falsified medicines are more likely if there is a weak regulatory system and supply chain. In order to tackle the issue of falsified medicines, a multisectoral approach is needed. This needs to involve law enforcement agencies alongside global public health stakeholders, from public as well as private sectors, and the media. 


\section{Pharmacovigilance}

Events caused by defective medicines are sometimes relatively difficult to distinguish from those considered to be the result of accidents, errors or adverse drug reactions. An example is the fentanyl transdermal patch. Fentanyl is a strong opioid analgesic (about 80 times stronger than morphine) used to treat chronic pain. ${ }^{23}$ It has a narrow therapeutic window, and an overdose can result in adverse effects, including respiratory arrest and death. Several deaths due to fentanyl patch overdose have been reported worldwide, ${ }^{24}$ including the $\mathrm{UK}^{25}$ Overdoses can be caused by excessive application of patches, incorrect product use (eg, cutting the patch) and exposing the patches or the skin to any kind of heat, which can dramatically increase the drug's absorption through the skin. ${ }^{24}$ Certain fentanyl patches and transdermal systems have been recalled in different countries, ${ }^{26} 27$ including the UK (table 1). The defects in all cases resulted from either a cut in one side of the fentanyl patch reservoir or self-activation of the transdermal system; both have the potential to cause overdose. In such cases, it can be difficult to distinguish between the events related to adverse drug reaction, misuse or accidents, and those that are caused by defective products. There is a possibility, therefore, that some cases of adverse events related to this defect have been attributed to the adverse-reaction nature of the drug and have gone unreported.

\section{Limitations}

The main limitation of the review was the lack of available data on the adverse events related to defective medicines. The data have been not provided to the authors by the MHRA or the manufacturers. A comparison between the expected risk and pharmacovigilance data could not be performed as pharmacovigilance reports in the UK are held by the MHRA and are not in the public domain. Thus, the clinical significance of the problem is unknown. Company-led recalls have been posted on the MHRA website since 2011; information on these recalls for previous years has not been provided. Owing to the lack of information made available, we were not able to determine the reason(s) for the rise in defective medicines.

\section{CONCLUSION}

The reporting of substandard medicines in the $\mathrm{UK}$ is on the rise. There was an increase from 5 incidents in 2001 to 50 in 2011. Parenteral formulations were most likely to be substandard. There is a greater likelihood of harm to the patient in association with contaminated parenteral formulations, but the clinical significance of the problem is unknown, due to the lack of information related to their toxicity. Healthcare providers should know how to assess the quality of medicines, particularly parenteral formulations for any sign that can be an indication of contamination and sterility failure.
Contributors TA performed the search, extracted the data and drafted the paper. HS double-checked the extracted data, conceived the idea and interpreted the results. IC had the original idea for the study. IC and TA designed the review and IC critically revised the manuscript and supervised the study. All authors approved the final version of the manuscript.

Funding This research received no specific grant from any funding agency in the public, commercial or not-for-profit sectors.

\section{Competing interests None.}

Provenance and peer review Not commissioned; externally peer reviewed.

Data sharing statement Extra data can be accessed through the Dryad data repository at http://datadryad.org/ with the doi:10.5061/dryad.jv3d2.

Open Access This is an Open Access article distributed in accordance with the Creative Commons Attribution Non Commercial (CC BY-NC 3.0) license, which permits others to distribute, remix, adapt, build upon this work noncommercially, and license their derivative works on different terms, provided the original work is properly cited and the use is non-commercial. See: http:// creativecommons.org/licenses/by-nc/3.0/

\section{REFERENCES}

1. Bate $R$, Jensen $P$, Hess $K$, et al. Substandard and falsified anti-tuberculosis drugs: a preliminary field analysis. Int $J$ Tuberc Lung Dis 2013;17:308-11.

2. Bate R, Coticelli $P$, Tren R, et al. Antimalarial drug quality in the most severely malarious parts of Africa-a six country study. PLoS ONE 2008;3:e2132.

3. Caudron JM, Ford N, Henkens $\mathrm{M}$, et al. Substandard medicines in resource-poor settings: a problem that can no longer be ignored. Trop Med Int Health 2008;13:1062-72.

4. Attaran A, Barry D, Basheer S, et al. How to achieve international action on falsified and substandard medicines. BMJ 2012;345:e7381.

5. European Commission. Policies to Combat Counterfeit Medicines, Contribution to Impact Assessment-2008, London. http://ec.europa. eu/health/files/counterf_par_trade/counterfeit-study-main-report_en. pdf (accessed 30 Jan 2012).

6. Williams A. Europe prepares to battle the counterfeiters. Pharm Technol Eur 2011;23:9-11.

7. MHRA. Defective Medicines Report Centre (2011). http://www.mhra gov.uk/Safetyinformation/Howwemonitorthesafetyofproducts/ Medicines/DefectiveMedicinesReportCentre/index.htm (accessed 30 Jan 2012).

8. MHRA. A Guide to Defective Medicinal Products. http://www.mhra. gov.uk/home/groups/is-lic/documents/publication/con007572.pdf (accessed 30 Jan 2012).

9. WHO. WHO's role in the prevention and control of medical products of compromised quality, safety and efficacy such as substandard/ spurious/falsely-labelled/falsified/counterfeit medical products. 2011. http://apps.who.int/gb/ssffc/pdf_files/A_SSFFC_WG2_3-en.pdf (accessed 1 Jun 2012)

10. MHRA. Falsified Medical Products Strategy (2012-2015). http:// www.mhra.gov.uk/home/groups/ei/documents/websiteresources/ con149816.pdf (accessed 15 Oct 2012).

11. WHOCC. ATC Structure and principles. http://www.whocc.no/atc/ structure and principles/ (accessed 30 Jan 2012).

12. MHRA. Counterfeit medicine recalls and previously seen counterfeits. http://www.mhra.gov.uk/Safetyinformation/

Generalsafetyinformationandadvice/Adviceandinformationforcon sumers/counterfeitmedicinesanddevices/FalsifiedMedicineRecallsand previouslyseencounterfeits/index.htm (accessed 15 Oct 2012).

13. HSCIC. Prescriptions Dispensed in the Community, Statistics for England (2001-2011). http://www.hscic.gov.uk/catalogue/PUB06941 (accessed 15 Dec 2012).

14. Davies E. More US citizens die from meningitis as scope of inquiry widens. BMJ 2012;345:e7095.

15. MHRA Annual Report and Accounts 2003/04. http://www.mhra.gov uk/home/groups/comms-ic/documents/websiteresources/con008340. pdf (accessed 17 Apr 2012).

16. MHRA annual statistics 2010/11. http://www.mhra.gov.uk/home/ groups/comms-ic/documents/websiteresources/con123239.pdf (accessed 17 Apr 2012).

17. Edwards IR. Fraudulent and substandard medicines. Getting away with murder? Drug Saf 2011;34:445-8. 
18. MHRA. Anti-counterfeiting strategy 2007-2010. http://www.mhra. gov.uk/home/groups/ei/documents/websiteresources/con2033156. pdf (accessed 15 Apr 2012).

19. European Alliance for Access to Safe Medicines. The counterfeiting superhighway. 2008. http://v35.pixelcms.com/ams/assets/ 312296678531/455_EAASM_counterfeiting\%20report_020608.pdf (accessed 5 May 2011).

20. Solomon S. BC woman killed by fake drugs bought online: 'Metal toxicity' from counterfeit pills reinforces danger of Internet meds. Nat Rev Med 2007. http://www.nationalreviewofmedicine.com/issue/ 2007/07_30/4_policy_politics_13.html (accessed 15 Dec 2012).

21. Chaubey S, Sangla K, Suthaharan E, et al. Severe hypoglycaemia associated with ingesting counterfeit medication. Med J Aust 2010;192:716-17.

22. Barber T, Jacyna M. Acute lead intoxication from medications purchased online presenting with recurrent abdominal pain and encephalopathy. J R Soc Med 2011;104:120-3.
23. Käferstein $\mathrm{H}$, Sticht $\mathrm{G}$. Comparison of nonradioactive microtiter plate enzyme immunoassays for the sensitive detection of fentanyl.

Forensic Sci Int 2000;113:353-7.

24. Jumbelic MI. Deaths with transdermal fentanyl patches. Am J Forensic Med Pathol 2010;31:18-21.

25. MHRA. Fentanyl patches: serious and fatal overdose from dosing errors, accidental exposure, and inappropriate use. Drug Saf 2008;2. http://www.mhra.gov.uk/Safetyinformation/DrugSafetyUpdate/ CON087796 (acessed 1 May 2011).

26. FDA. Duragesic (fentanyl transdermal system), class 1 recall notice. 2004. http://www.fda.gov/Safety/MedWatch/SafetyInformation/ SafetyAlertsforHumanMedicalProducts/ucm166410.htm (accessed 1 May 2011).

27. Product Recalls Australia, fentanyl transdermal patches. 2005. http:// www.recalls.gov.au/content/index.phtml/itemld/954146 (accessed 1 May 2011). 